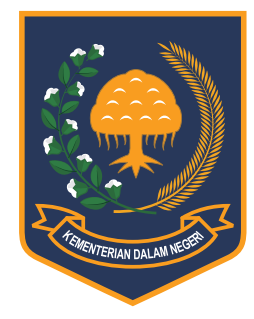

Jurnal Bina Praja 8 (2) (2016): 253-262

Jurnal Bina Praja

e-ISSN: 2503-3360 | p-ISSN: 2085-4323

Accreditation Number

735/AU2/P2MI-LIPI/04/2016

http://jurnal.kemendagri.go.id/index.php/jbp/index

\title{
Concurrent Village Head Election (Pilkades) Disputes (ANAlysis of Handling PATTERn AND Dispute Resolution Process In TAPOS, TAlagasari, AND DUKUH Villages OF TANGERANG REGENCY)
}

\author{
Ray Septianis Kartika ${ }^{1, *}$ \\ ${ }^{1}$ Research and Development Agency, Ministry of Home Affairs (BPP Kemendagri) \\ Jl. Kramat Raya No. 132, Senen, Jakarta Pusat
}

Received: 5 April 2016; Accepted: 15 October 2016; Published online: 30 November 2016

DOI: $10.21787 /$ ibp.08.2016.253-262

\begin{abstract}
The appointment of a village head often causes turmoil in some regions. Ranging from internal problem to the resolution through legal channels. This study aims to assess the extent of the Pilkades disputes in Tapos, Talagasari, and Dukuh Villages in Tangerang Regency. By using qualitative analytical descriptive method, the results of this study are (1) the absence of Pilkades dispute resolution medium at the regency, district and village levels, (2) by regulation, PP No 72 of 2005 does not explain the categorization of violations and sanctions against offenders, (3) There is an implied term campaign ends, as amended, Regulation 7 of 2006 article 54, paragraph 8, (4) lack of traction on the role of Head in controlling and supervising corresponding PP No 72 of 2005 and Regulation 7 of 2006, (5) the lack of an audit role, (6) the absence of a competent team of investigators administration. Suggestions that we can recommend is (1) to make the legislation or local regulations that elevate one article about the elections and dispute resolution, (2) Effectiveness muspika role in the elections and, (3) promoting Pilkades order.
\end{abstract}

Keywords: dispute, Pilkades, village government.

\section{INTRODUCTION}

Village head election is a democratic party in the village. The appointment of the village head as one of the elements of village government often causes turmoil in some areas. the Pilkades committee which takes the decision on the finalization of the elections acts extremely, and the participants are anarchistic causing social unrest and public lies. Plus the actions undertaken by one of the elements lead to crime, civil, or administrative defect. A study research by the Ministry of Justice and Human Rights (2011: 10), as quoted by Bisri, stated that there is no political guarantee on the result of the elections. The deadlock on the disputes resolution not only sharpens the conflict but could make the actors frustrated. Based on this study, it can be said that Pilkades accountability is still low and the democracy in the villages is still apparent. The legal uncertainty causes the conflict in the organization of the elections, starting from the election process to the execution of the elected village head.

Pilkades euphoria, which blinds the system and darkens truth, is able to position Pilkades in an unhealthy political game. The violation of Pilkades seems to be given a green light and tough to examine. The fact that the violation is deadlocked even after being attempted by the recalculation of the vote count, even by rescheduling Pilkades. The actors who play have the intrigue and dirty strategy to legalize the untruths. Many actors were shackled and changed hiding behind the authority. the demand for transparency is being subordinated to the elements of their interests. It resulted in the decadence of public confidence in the results of the elections and is increasingly becoming a public

\footnotetext{
* Corresponding Author

Phone : +6289611756331

Email : raseka1979@gmail.com
} 
inquiry. Where will the village democracy go? The village democracy direction is framed in a mirror of fight that needs to be addressed in order to become a democracy in line with the expectations.

The democracy that raises controversy also occurred in Tangerang Regency as the locus of this study, as described in Tempo media. The concurrent Pilkades in Tangerang Regency is in accordance with the Regent Decree No 141/Kep.100-huk/2013 has been up to the court. The realm of dispute resolution is at points of prone areas. Of the 149 villages that carry Pilkades, there are 39 villages identified as conflict-prone, as disclosed by the Head of the Village Administration on an internet site. The trigger of conflicts is caused by the inaccuracy of concurrent Pilkades administration system that works and the final violation execution of Pilkades winner.

The conflict of concurrent Pilkades conducted by Tangerang District may also be experienced by other regions. It is the overview of a research conducted by Halili (2009: 99) that the practice of money politics that lasted intensively increasing the formal participation of voters. In the same context, Zaenuri (2014: 74) identifies that the main factor determining the election of village heads is their practice of money politics and policy on setting up village elections in accordance with the aspirations and values developed in the community. It is also strengthened by a research result of Anam (2014: 73) in his research on the dispute settlement of village head elections result found no mediation agency created by the Regent/Mayor. Similarly, Putra (2015: 18) mentioned in his research related to Dispute Settlement of Village Head Election resulted in establishing a special court in resolving the problem. The variation of research results implies that the polemic of Pilkades with different root causes obstruction of democracy in the village.

From the results of research that have been mentioned above, this research paper is different from the previous studies. This is due to the discussion of the Pilkades dispute handling pattern that occurred in Tangerang Regency. In addition to viewing the factors behind the conflict, it also provides a formula in handling the dispute through consultation and the Administrative Court (PTUN). Both of these solutions are seen as the formula of Pilkades dispute proper handling. Of course, also is adjusted by the characteristics of the political actors and the causes of the dispute. In addition, this paper also weaves stages of Pilkades dispute resolution processes in Tangerang Regency from the mapping of the disputed village to the level of dispute resolution.

In theory, the village head elections can not be separated from society's political participation. Budiardjo (2009: 367) stated that political participation is the activity of a person or group of people to participate actively in political life, among others by choosing the leadership of the State and directly or indirectly, influence government policy. According to Closky in the International encyclopedia of the social sciences, as cited by Budiardjo (1996: 183), political participation is a voluntary activity of citizens of the communities in which they take part in the electoral process and the authorities directly or indirectly in the process of public policy formation. 3 It is similar to the statement by Soemarsono (2002: 4.5) that political participation is a measure to determine the quality of the state citizens capability to interpret a number of symbols of power into personal symbols. Political participation is the process of reformulating the symbols of the communication based on the reference levels owned either privately or groups in the form of attitude and behavior activities.

Village head election according to Anwar (2008: 1) can be considered as a neglected potential. The potential here not only pragmatically defined as something that can produce sheets of rupiahs or pieces of dollars. But rather on the negative potential such as a split society. It is the result of the severity of the confrontation of candidates and supporters face to face in fighting for each victory.

Thus, the formulation of the problem in this study is of three things, namely (1) the mechanism of concurrent pilkades candidacy process, (2) the causative factor of the occurrence of pilkades dispute, and (3) pilkades dispute handling patterns. Meanwhile, the purposes of this study are (1) to identify the process of concurrent pilkades candidacy, (2) to know the causative factor of the occurrence of pilkades dispute, and (3) to analyze the handling pattern of concurrent pilkades.

\section{Method}

This research uses an analytical descriptive method with a qualitative approach. The aim is to describe the situation of village head elections. This study took samples in Tangerang Regency of Banten province, namely Tagalsari Village, Dukuh Village of Cikupa District, as well as Tapos Village Tiga Raksa District. The collection of the locus is with a random technique, which begins by mapping between the villages who face criminal charges, villages facing a lawsuit to the Administrative Court, and the villages resolving their pilkades disputes by means of deliberation. Of the 21 vulnerable villages in Tangerang Regency, the team conducted a lottery such as social gathering and the name of the village came out first was used as the first sample and then continued until 3 samples were collected.

Informants on this study are the Apparatus of Village Development Division of Tangerang Regency Government as the party who facilitates 


\begin{tabular}{ccccc} 
Village & Number of Citizen & Number of DPT & $\begin{array}{c}\text { Number of Village Head } \\
\text { Prospective Candidates }\end{array}$ & $\begin{array}{c}\text { Number of Village Head } \\
\text { Candidates }\end{array}$ \\
Tapos & 7,646 & 5,827 & 2 persons & 2 persons \\
\hline Talagasari & 10,035 & 9,807 & 6 persons & 6 persons \\
\hline Dukuh & 8,389 & 6,889 & 2 persons & 2 persons \\
\hline
\end{tabular}

Source: Field Secondary Data, 2013

the implementation of Pilkades, the elected village head of 2013-2019, Chairman of the BPD, and 1 (one) person who is a member of the pilkades committee. The data analysis technique is conducted qualitatively by stating objectively the findings in the field, further linking these findings to the theory and interpret the into the mind of the author so can be found the validity of the existing data.

\section{RESULT AND DISCUSSION}

\section{A. Candidacy Process of Concurrent Pilkades in Sample Location}

Pilkades is the authority of the Regency as stated in Tangerang Regency Local Regulation No 7 of 2006 on Village Government, and Tangerang Regent Regulation No 16 of 2007 on the Guidelines for Selection of Village Head, and Regent Decree No 141/Kep.100-huk/2013 on The Implementation of Concurrent Village Head Election in Tangerang Regency. Village election is very closely related to the community, where the community as sympathizers belonging to the list of voters and candidates of the village head. For more details can be seen in Table 1 .

The data in Table 1 shows that Talagasari Village has the largest population if compared to Tapos Village and Dukuh Village. Automatically, the number of the biggest DPT is owned by Talagasari village. In fact, the number of DPT does not necessarily determine the total of vote count. Based on the data that can be collected, Desa Tapos earned as much as 5,208 votes from the total of 5,827 DPT, Talagasari Village earned as much as 8,136 of 9,807 DPT, and Dukuh Village earned as much as 7,926 vote count of 6,889 DPT.

Pilkades Committee functions to curb the administration. The composition of the existing committee is: Tapos Village with 13 people, Talagasari Village with 50 people, and Dukuh Village with 29 people. Talagasari Village has the highest personnel than both villages. The performance of the committee in Telagasari Village in the administration can be seen the process of pre-Pilkades. Unlike the case with Dukuh Village that has an excellent administrative completeness, in particular for prePilkades administration, implementation, and post-
Pilkades. In Tapos Village, only has administration for pre-Pilkades. The candidacy of the pilkades in three samples is conducted as follows: First, establish a village head election committee in charge of checking the identity of candidates based on specified requirements, conduct polling, and report the implementation of the elections to BPD. Second, conduct a census to determine the DPT, Third, do Networking and screening on prospective village heads, Fourth, screening prospective candidates, and Fifth, make the appointment of eligible candidates for the election.

The Local Regulation No 7 of 2006 article 45 paragraph (1) mentions that the election committee consists of representatives from the village apparatus, the board of community organizations, and community leaders. But on the same regulation in paragraph (5) stipulates that the chairman of the committee can be comprised of members of the BPD or members of village community institution if desired deliberations. Inconsistencies in Regulation No 7 of 2006 on Village implies that between one verse and another verse intersect. In fact, when examined in detail, the position of BPD as the chairman of the committee possibly will not be neutral. Its position as the party to legalize the administration document of Pilkades becomes a dilemma, between the duties and status of Pilkades committee. Similarly, in the composition of the committee, Talagasari Village has more committee than Tapos Village, and Talagasari can have a complex administrative system. But in reality, Talagasari Village does not comply the Pilkades administration.

\section{B. Factors Causing Pilkades Dispute}

Pilkades disputes are backed by some of the planned and unplanned things. As the result of research by Susanti (2011: 62) that states the impact of pilkades caused by intimidation from those who lose. The disagreement on the result of the pilkades is the attempt to disrupt the election harmony. The commitment to teaching the community through political participation becomes an illusion when the plaintiffs only show selfishness and democracy unfairness. When the team conducted an analysis, 
Table 2.

Pilkades Problems Analysis

\begin{tabular}{|c|c|c|c|}
\hline Village/District & Legal Act & Problem & Analysis \\
\hline $\begin{array}{c}\text { Dukuh of Cikupa } \\
\text { District }\end{array}$ & $\begin{array}{c}\text { Administrative } \\
\text { Court } \\
\text { (PTUN) }\end{array}$ & $\begin{array}{l}\text { - Money politic } \\
\text { - The committee is not neutral } \\
\text { - An indication of bubbling the } \\
\text { ballot papers }\end{array}$ & $\begin{array}{l}\text { - A lawsuit on the bubbling of vote has not been proven valid } \\
\text { for the minutes of the pilkades result are signed by the } \\
\text { witness of the prospective village head. } \\
\text { - A waiver of the prospective village head to cover the } \\
\text { Pilkades with the signature on the IDR6,000 stamp. } \\
\text { - A statement from the prospective village head that the } \\
\text { Pilkades and have been implemented in accordance with } \\
\text { the procedure, and Pilkades actually held by the citizens in } \\
\text { a direct, public, free, secret, and fair manner. } \\
\text { - The pledge of the village head candidates to acknowledge } \\
\text { DPT according to the procedure is only on paper. } \\
\text { - Minutes of the pilkades committee ballot box opening are } \\
\text { appropriately procedural. }\end{array}$ \\
\hline Talagasari & $\begin{array}{c}\text { Administrative } \\
\text { Court } \\
\text { (PTUN) }\end{array}$ & $\begin{array}{l}\text { The difference between the } \\
\text { number of ballots that go } \\
\text { into the ballot box with the } \\
\text { calculation result. }\end{array}$ & $\begin{array}{l}\text { - There is a delay in the counting of ballots. } \\
\text { - The minutes are signed by the candidate's witnesses, } \\
\text { the committee chairman, and the chairman of BPD as } \\
\text { witnessed by the Act. Village Head, officers from the } \\
\text { district, binamasa and, non-commissioned village builder } \\
\text { (babinsa). } \\
\text { - Incomplete reporting file. }\end{array}$ \\
\hline
\end{tabular}

Source: Field Secondary Data, 2013

it will depart from the phenomenon on behalf of the disabled administration as the consequence of failure of pilkades organization failure in 2013. For more details, can be seen from the data in Table 2 .

of the 16 problematic villages in Tangerang Regency during the concurrent pilkades, it was just Tapos Village that can be resolved by consensus. Tapos Village could become an example for Dukuh Village as well as Talagasari Village of Cikupa District to attempt a deliberation on all issues in order to get a way out. Of the two samples, namely Dukuh Village and Talagasari Village of Cikupa District, are still sheathed emotionally. The cause of the dispute is resulting in a flawed administration of the pilkades as a result of dissatisfaction with the outcome of the vote. Although the minutes of the vote were attached, but still, the plaintiffs insisted on their decision. When associated with the order of the pilkades, it is believed to (a) be proven in conducting activities as individuals or groups, ask the voters to not exercise their voting rights by persuasion or coercion to deter voters to not be present and to not choose, (b) be proven to damage, screw deliberately the election premise and equipment, (c) the Committee is proven to receive money or goods from village head candidates for their own interests will be directly proposed to BPD to be dismissed from the committee and be replaced and revoked of their right to vote, (e) Residents of Dukuh Village as the owner of the right to vote are proven to receive money or goods from village head candidates for their personal interests will be revoked of their voting rights.

\section{The Handling Pattern of Concurrent Pilkades}

In the Government Regulation (PP) No 72 of 2005, in detail it does not mention the types of violations and sanctions imposed on each violator but the region is given an authority in determining the sanctions in case of violations in its territory. With capitalize selfishness of the plaintiffs, no doubt that the pilkades dispute does not find a way out. On the contrary, they insist that their argument is

Table 3.

Pilkades Handling Pattern

\begin{tabular}{cl} 
Village Name & \multicolumn{1}{c}{ Remarks } \\
Talagasari Village, Cikupa District & $\begin{array}{l}\text { Has been mediated by the Regency Government and Muspika on } 15 \\
\text { July } 2013 \text { but the problem continues to legal action }\end{array}$ \\
\hline Dukuh Village, Cikupa District & $\begin{array}{l}\text { Has been mediated by the Regency Government and Muspika on } 15 \\
\text { July } 2013 \text { but the problem continues to legal action }\end{array}$ \\
\hline Tapos Village, Tigakarsa District & Has been resolved with a deliberation \\
\hline
\end{tabular}

Source: Field Secondary Data, 2013 


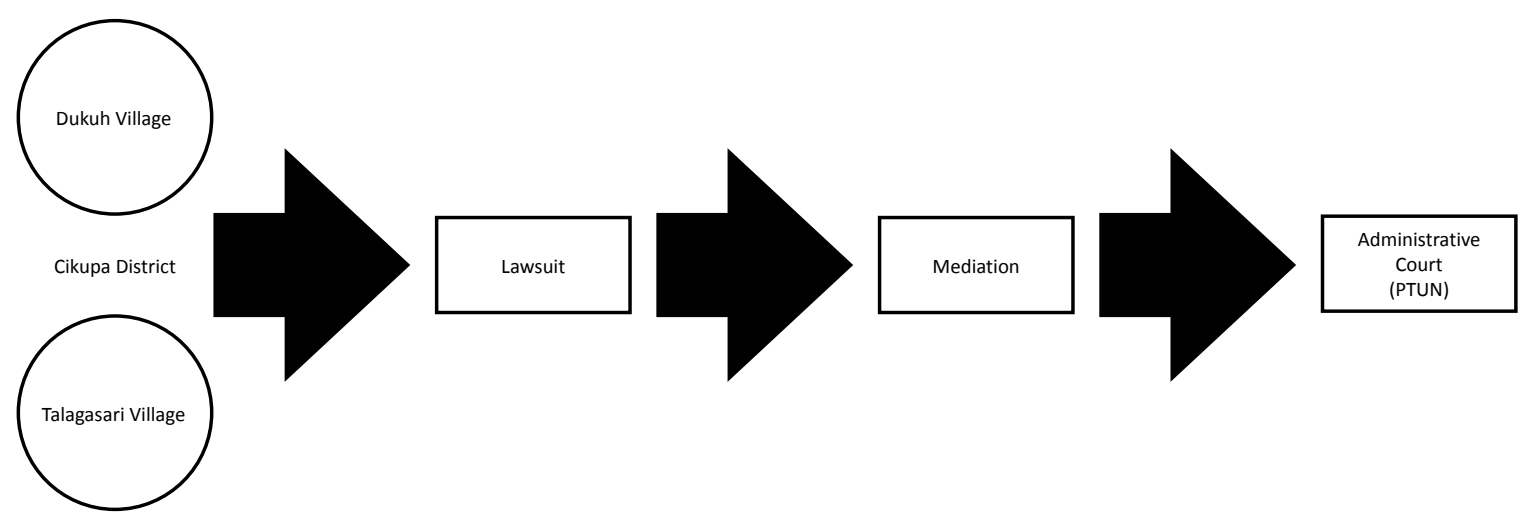

Figure 1. Lawsuit Flow of Dukuh Village and Talagasari Village of Cikupa District

the utmost truth. While actually, by maintaining their own opinion, it will affect the very strong implication for the implementation of the village administration. The description of the Pilkades handling pattern in accordance with the level of the existing problems can be seen in Table 3 .

Specifically, at each sample location, it experienced a fairly complicated problem. In Dukuh Village and Talagasari Village, they have undertaken legal actions and the documentation is forwarded to the administrative court.

Although mediation has been taken by the regency government, but the problem could not be resolved and the plaintiffs continue to a higher realm that is the legal process. The trial goes on, and the plaintiffs insisted that the implementation of the pilkades illegal. By summoning the witnesses, including the Regent as an expert witness who is seen to violate the law by inaugurating the elected village head in Talagasari Village and Dukuh Village of Cikupa District. The witness still can not justify the pilkades. The inequality of the filing in the implementation of the pilkades that aggravates Talagasari Village and Dukuh Village in the administrative court process becomes a black note for these two villages since the pilkades document is one of the requirements that must be completed in accordance with the applicable procedure.

In addition to the lane taken by Talagasari Village and Dukuh Village of Cikupa District, below the author will also illustrate the flow of handling disputes in Tapos village in Figure 2.

The implementation of Pilkades in the three samples as the point of conflict-prone regions are all villages with the same typology as agricultural areas. Although surrounded by the industry that is quite large, with the village potential of adequate farmland, Tangerang District is considered to have surplus villages. But in line with the development, the potential of the villages is essential to the implementation of pilkades. Judging from the enthusiasm of the prospective village heads whose ambition are to become the elected village heads, as well as the policy of the Province in the provision of allowance to village heads, so that it becomes an added value to Tangerang District to attract prospective village heads to participate because of the benefits they will receive.

As described previously, of the 147 villages that carry out the concurrent pilkades in Tangerang District, 16 villages are identified as problematic. According to Anwar (2008: 1), the negative side of pilkades can be considered as a neglected potential that causes clashes in the community. This is due to the rigors of confrontation among candidates and supporters in face-to-face manner fighting for each victory. In fact, sometimes forgetting the social etiquette and democratic values. From the positive side, pilkades is a way of achieving good governance as proposed by UNDP (1997), with the basic principle as follows:

1. Participation: Pilkades has been able to

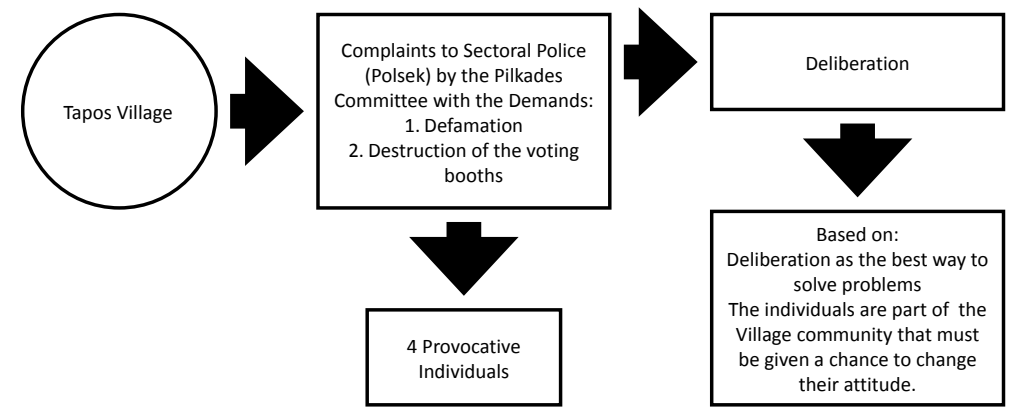

Figure 2. Suit Flow of Tapos Village 
increase the participation of the community to speak up and to give opinion. Pilkades has been reflecting the aspirations of the people. Judging from the number of voters list for Tapos with the number of DPT of 5,827 (5,208 votes) and around $0.11 \%$, Talagasari of 9,807 $(8,136$ votes) and around $0.12 \%$, and Dukuh of 6,789 (6,789 votes) and around $0.10 \%$.

2. Law enforcement: The local government needs to seek wise and effective local regulations, as well as supported by fair law enforcement through the corruption eradication.

3. Transparency where the change of people intelligence to the governance, the increase of public trust, the increasing number of people who participate in the development and the reduction of laws and regulations violation.

4. Equality, the data from the prospective village heads that enliven the pilkades are 547 people and the majority is dominated by 526 men and about 21 women. Although women are of minimal participation, but it could be a measure that women are enthusiastic to political developments in the village.

5. Responsiveness, in which the local government needs to establish a communication line to accommodate the aspirations of the community in terms of policy making. Tangerang District government performs mediation for the disputing villages on the implementation of the pilkades as the instruction done by Tangerang Regent No 141/1611-Pemdes/2013 on the Facilitation of Pilkades Implementation.

6. Insights into the future by developing a region based on a clear vision and strategy and engaging citizens in the entire development process. In this case, the village head candidates have a vision and mission for the future rural programs and strategies to attract the masses' sympathy, either a sympathetic campaign or an open campaign in a field. Although in the Tangerang District Regulation Chapter $\mathrm{V}$ of article 39 paragraph (d) explains that those who can be selected as the village head must meet the educational requirement of at least junior high school. In fact, the educational background of the candidates for village heads in Tangerang District nevertheless does not discourage them in launching a strategy to ensure victory over the opposition.

7. Accountability, which is the entire policymakers at all levels should be accountable for the work to the public. The monitoring system needs to be strengthened and the audit results should be published. If there is an error, must be sanctioned. In this case, Pilkades Budgeting has never been audited, just some sort of reporting to the public. The tipping point is the increased trust and satisfaction of the people to the government, the growth of public awareness, the increase of the representation based on the choice and the interests of the society, and the reduced cases of corruption.

8. Supervision, which is to improve surveillance efforts on governance and development to seek the involvement of the private sector and the bigger public. The monitoring carried out by the authorized institutions needs to provide opportunities for the community and community organizations to actively participate in the monitoring, evaluation, and oversight of the work, according to the field. The Pilkades supervision is conducted starting from the beginning to the end process, with the involvement of other parties such as muspika, Executive Conference (muspida), and the Chief of Resort Police (Polres).

9. Efficiency \& Effectiveness, which are ensuring the service to the community by using the available resources optimally. In this case, the use and the utilization of the Pilkades committee are adapted to current needs. Each village committee is very varied in number, even there is an existing system that uses barcode, which is considered to make the budget efficient and to minimize the number of committee in the Pilkades.

10. Professionalism, which is by enhancing the capability and the moral of government administrators to be able to provide the service that is easy, fast, precise, and with affordable cost. The purpose is creating an effective professional bureaucracy.

The Pilkades discourse in developing the village is a manifestation of a good governance form. The Pilkades development that has been made on June 30, 2013, despite ended in polemic, does not mean that a good governance is not achieved. It is necessary for an administrative proof. As what happened in Talagasari Village and Dukuh Village of Cikupa District, which has reported the Pilkades Committee and the local parliament (BPD) head to the State Administrative Court. The irregularities of Pilkades in Talagasari Village and Dukuh Village should not serve as the mere issue, but the process of tracking based on the principle of innocence must be the attention to us all. Therefore, the decision of the Pilkades result is not included in the administrative decision pursuant to Article 2 letter g of Law No 5 of 1986. In the case of Pilkades, the plaintiffs are the Pilkades participants arguing that there are frauds, whether committed by the committee as well as the head of BPD. The case of Pilkades will have a permanent legal force merely up to the level of the High Court because it is included in the kind of cases that can not be filed as a cessation. So that today, 
there are many cases of Pilkades examined by the Administrative Court and decided as the absolute authority of the Administrative Court.

For the dispute that can be reconciled amicably as in Tapos Village, a deliberation is considered able to be used as the solution to solve the problems in the community, especially the problem faced during the Pilkades. Each deliberation participant has an equal right to express opinions and have the same obligations to carry out the decisions of deliberation, so that there is equality between all deliberation participants, no matter what their position is. What must be considered in the deliberation is the proposal or opinion of a person, not who the person is. So that all participants have an active role, the same rights, and obligations in the implementation of the deliberation. Especially for Tapos Village, the deliberation is an instrument to reconcile the condition that may invite anarchy. Because: First, the two conflicting parties realize that a deliberation is a tool used to reach an agreement. Second, both sides value the opinions and arguments that cause mass riot during Pilkades.

From what is described above, from the outline of the implementation of Pilkades, it can be seen that a village has a very big authority in organizing a Pilkades, starting from the formation of the pilkades committee tailored to the needs and abilities of the prospective village heads up to the level of execution on the determination of elected village heads. Pilkades is also a learning tool for village communities to organize and to grind the ability of good management and managerial in regulating a Pilkades. It can be said so from the analysis of the Team, which can be identified as follows: (1) Public participation is not in terms of contributing to the right to vote, but in contributing in choosing the head of the BPD and the Pilkades committee that is very good, (2) Even with limited human resources that are capable of managing Pilkades, but the human resources are able to present the pilkades in accordance with technological developments as the one encountered in Tapos Village of Tigaraksa District. The pilkades in the village has been using a barcode system to streamline the expenditure on the pilkades and, (3) the dispute of Pilkades depends on the candidate's commitment to accept all final decision of the pilkades result. Because the village is not a competitive event, but the village is an event to work together and mutually motivate whoever the leader is.

Not only that, the agreements contained in the minutes and other legal documents become silent witnesses that the prospective village heads who are part of the pilkades are figures with full dedication and commitment to building their territory. Responsible not only for carrying out the work but take their responsibility seriously in undertaking agreements made not only spoken but written.

Thus, the Pilkades dispute is not something easy to handle, because it involves a conflict between two or more people. The dispute has been considered loaded with personal interest, egoism, and extreme attitude towards the success of the pilkades is absolutely in need of the solution to avoid the crisis of trust in the implementation of pilkades.

From the identification result of the surveyor team, analyzed some of the findings related to Pilkades disputes in some samples, namely:

1. On the regulatory aspect, first, the absence of medium to resolve the Pilkades disputes either at regency, district, or village level. Second, concurrent Pilkades in 2013 did not run favorably if compared to 2007. Third, the amount of inaccuracies in regulation as implied in Government Regulation (PP) No 72 of 2005 on Village, the Regent Regulation No 7 of 2006 on Village Governance and the order of the pilkades with specifications as follows (a) Government Regulation No 72 of 2005 on Village does not explain the categorization of violations and sanctions for offenders, (b) The regulations of Pilkades in three samples do not include the end period of the campaign as the amendment of Local Regulation No 7 of 2006 Article 54 paragraph (8), (c) The role of a District Head in facilitating the implementation of the pilkades through control and supervision is not confirmed in PP 72 of 2005 on Village and Local Regulation No 7 of 2006 on Village Governance.

2. In the aspect of budgeting, first, the role of the Regency is only to facilitate the process of pilkades from the terms of budgeting in the amount of IDR15 million/ village. And the implementation is fully given to village as the Local Regulation No 6 of 2007. Second, the budgeting of Pilkades in every region of the sample varied if viewed from the number of households that are all borne by the prospective village heads and regency accompanying fund. Third, lack of supervision on pilkades, and even the role of the audit does not play in it. Fourth, the Budget management of pilkades is given entirely to the BPD.

3. In the aspect of political knowledge, which is the high public awareness of the pilkades, being critical to the implementation of Pilkades especially when found some deviations, the high knowledge of the prospective village heads in political maneuvering, especially in political marketing strategy. There are three (3) approaches to the political marketing strategy, namely (a) Push Marketing, where candidates or political parties try to get support through stimulants provided directly to the voters, 


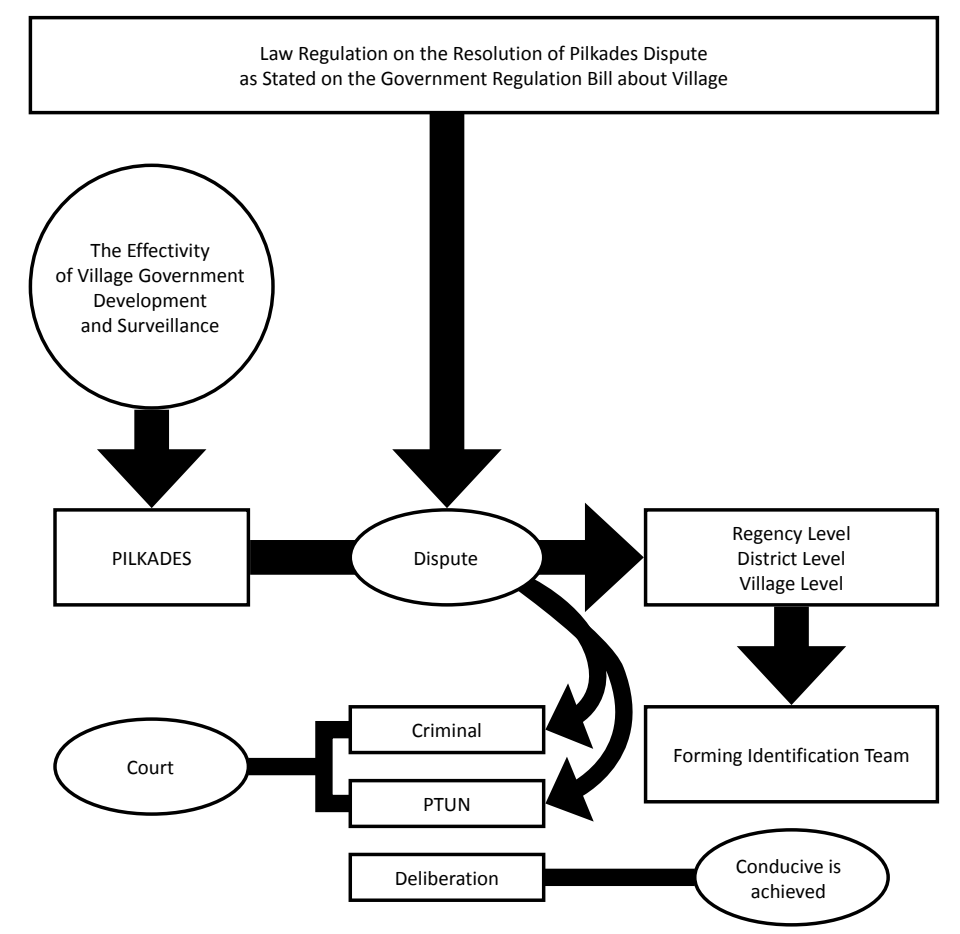

Figure 3. The Flow of Pilkades Dispute Handling

(b) Pass Marketing, where the marketing of political products is through influential persons or groups capable of influencing the opinion of voters, (c) Pull marketing, where the marketing of political products is through mass media, which focuses on the image of the political product. These three strategies are exactly used by the prospective village heads to intensify their political strategy. In fact, some people still choose a charismatic village head. In a way that the village head has a charisma that will greatly influence the progress of the village.

4. In the administration aspect, discovered the absence of a competent special investigation team for administration, the minutes are not all known by all prospective village heads such as the minutes of prospective village heads. The administrating system is still closed to the public, the committee of Pilkades who know the evidence of the administration, so that the violations that happen involve elements of Pilkades committee, as happened in Dukuh village and Talagasari Village of Cikupa District.

5. In the aspect of Pilkades dispute, it is suspected that the settlement of disputes through the administrative court is not considered appropriate since the Administrative Court does not investigate/receive comprehensive evidence from the plaintiffs. As a result, the process of the trial runs without valid proof, high attitude of selfishness, and unprofessionalism from the prospective village heads is more dominant than the attitude of sportsmanship and could not sort out which one is personal interest and which one is group interest, which impacts the mass riots on the re-implementation of Pilkades as happened in Tapos Village of Tigaraksa District. While the resolving with deliberation in a family manner is seen as an accurate method of settling for a deal that took place between the two sides in the conflict. Sit together to discuss solutions, without violence and arrogance. It is not yet considered and addressed by Dukuh Village and Talagasari Village of Cikupa District in taking the middle road on Pilkades dispute resolution.

Thus, the Pilkades that run with a good corridor is the Pilkades to realize democracy in the village.The mechanism of Pilkades administrating and the mechanism of reporting are absolutely in accordance with the stages of Pilkades. The case revealed is a fraction that is likely to occur in other regions. All are due to the pilkades administration system that does not fit the norm and has the essential in causing distrust motion against the government of the village. Based on this, the TEAM will provide a recommendation of the Pilkades flow in handling disputes as set forth in Figure 3.

Related to Figure 3, the effectiveness of the implementation and development of the village governance in the implementation of the pilkades can run in accordance with the actual corridor especially in terms of (1) Guidance and supervision during the initial process of the pilkades, starting 
from the selecting of prospective village heads to determining the prospective village heads, and the formation of Pilkades committee, and socialization on voting, (2) Guidance and supervision during the implementation of the pilkades starting from voting and the vote counting of Pilkades committee, supervision while attending a meeting for the counting of votes, supervision at the time of the ballot box opening, (3) Guidance and supervision after the pilkades starting from the ratification of the elected village heads and the inauguration of the elected village heads.

\section{Conclusion}

The pilkades carried out in three villages: First, the nomination process of the pilkades conducted in the three villages has been stipulated in Local Regulation No 7 of 2006 on article 50 of the Village Government, among others is related to the executor, cost, method, material, equipment, time, place, planning, implementation, monitoring, and result. Second, the cause of the pilkades dispute is dominated by the pilkades stages procedure that is not suitable with the mechanism which implied violation on the Pilkades order, bubbling votes, suspicion to the pilkades committee's performance, money politics, inaccuracies on DPT, the stages of the pilkades with the absence of minutes-taking event, suspicion towards the administrative records of one candidate for village head. Third, the pattern of handling the pilkades dispute and at the District level has made mediation by inviting the disputing parties, the district as the facilitation to examine the administrative records. If the mediation is unsuccessful, then the plaintiffs continue their complaint to a legal action. The suggestions from us are:

1. For the Central Government (1) can follow up the results of this study to make a draft government regulation on Village as a followup of the Village Law. Of course, by including a clause for settlement of Pilkades dispute. (2) Make a Minister of Home Affairs Circular which content instructs the Regents in the whole territory of Indonesia to resolve the dispute over the pilkades in accordance with the policies of each regent.

2. For Regency Governments (1) can make a regulation related to the settlement of the pilkades disputes stipulated in Local Regulation, (2) form an Independent Team for identifying and verifying the administrative files and Pilkades budgeting, (3) establish an evaluator team specifically to evaluate Pilkades in terms of the pilkades implementation and after the pilkades, (4) instruct the entire village to document the implementation of the pilkades visually as a step of obtaining evidence that is more valid when a dispute occurs, (5) revise Local Regulation No 7 of 2006 on Village Governance under Article 39 and also add a clause that outlines the role of the District Head in pilkades dispute resolution, make effective on the role of muspida in the implementation of Pilkades.

3. For the Regency Government, to make effective the role of muspika in the implementation of Pilkades.

4. For the Village Government, (1) disseminating the Pilkades code of conduct, (2) including the code of conduct regulation of the pilkades and the use of symbols, colors, or images, (3) making an official report with a signature by the Head of the BPD, the Committee of Pilkades, and candidates for village head, (4) the village head candidate must understand peace declaration signed by muspika, candidates for village heads, the committee chairman, and BPD to uphold fairness, (5) the necessity for the involvement of community leaders and religious leaders to mediate with the disputing parties.

\section{ACKNOWLEDGEMENT}

I would like to express my gratitude to Mr. Jan Pieter for giving the opportunity in writing this study. The informants in the locus of Banten Regency, Village Head of Tapos, Village Head of Dukuh, and Village Head of Talagasari for the information, cooperation, and communication, as well as the Examination Team of the Concurrent Pilkades which has put the effort together in collecting the data. May God repay all and the readers will gain maghfirah of this study. Amen.

\section{REFERENCES}

Anam, K. (2014). Penyelesaian Perselisihan Hasil Pemilihan Kepala Desa Menurut Undangundang Nomor 6 Tahun 2014 tentang Desa (Master Thesis). Universitas Jember.

Anwar, N. (2008). Pilkades, Soko Guru Pemilu Langsung. Gagasan Hukum. Retrieved 5 March 2016, from https://gagasanhukum.wordpress. com/2008/07/24/pilkades-soko-gurupemilu-langsung/.

Budiardjo, M. (1996). Demokrasi Pancasila. Jakarta: Gramedia Pustaka Utama.

Budiardjo, M. (2009). Dasar-dasar Ilmu Politik. Jakarta: Gramedia Pustaka Utama.

Halili,. (2009). Praktik Politik Uang dalam Pemilihan Kepala Desa (Studi di Desa Pakandangan Barat Bluto Sumenep Madura). Jurnal Penelitian Humaniora, 14(2), 99-112.

Ministry of Law and Human Rights,. (2005). Government Regulation No 72 of 2005 on 
Village. Jakarta: Ministry of Law and Human Rights.

Putra, B. (2015). Model Penyelesaian Perselisihan Hasil Pemilihan Kepala Desa. Jurnal Hukum. Retrieved from http://hukum.studentjournal. ub.ac.id/index.php/hukum/article/ view/1015.

Soemarsono,. (2002). Komunikasi Politik. Depok: Raja Grafindo Persada.

Susanti, E. (2011). Dampak Konflik Pilkades (Studi Kasus di Desa Ngares Kecamatan Trenggalek
Kabupaten Trenggalek) (Undergraduate Thesis). Universitas Jember.

Tangerang Regency,. (2006). Regent Regulation No 7 of 2006 on Village Governance. Tangerang: Tangerang Regency.

Zaenuri, M. (2014). Pemilihan Kepala Desa yang Bersih dan Bermartabat dalam Rangka Penguatan Pemerintahan Desa (Kajian Tentang Pencegahan dan Penyelesaian Praktik Uang dalam Pilkades di Kecamatan Jekulo) (Master Thesis). Universitas Muria Kudus. 